Jurnal Pendidikan Matematika Undiksha, Volume IX No 1, April 2018

e-ISNN:2599-2600; p-ISNN: 2613-9677

\title{
EFEKTIVITAS MODEL PEMBELAJARAN PENEMUAN TERBIMBING BERBANTUAN GEOGEBRA TERHADAP PEMAHAMAN KONSEP MATEMATIKA SISWA SMP
}

\author{
K.R.A. Septiana, N.N.Parwati, I.G.N.Y.Hartawan \\ Jurusan Pendidikan Matematika, Universitas Pendidikan Ganesha \\ Singaraja, Indonesia \\ e-mail: rikoagus77@yahoo.com,nyoman.parwati@undiksha.ac.id, \\ hartawan.math@gmail.com
}

\begin{abstract}
ABSTRAK
Penelitian ini bertujuan untuk mengetahui ada tidaknya perbedaan pemahaman konsep matematika antara siswa yang mengikuti pembelajaran dengan model penemuan terbimbing berbantuan GeoGebra, pembelajaran dengan model penemuan terbimbing, dan pembelajaran dengan model konvensional. Dari perbedaan tersebut diselidiki kelompok mana yang memiliki pemahaman konsep matematika lebih baik. Penelitian kuasi eksperimen ini menggunakan post-test only control group design. Populasi penelitian ini adalah siswa kelas VII SMP Negeri 2 Seririt tahun pelajaran 2016/2017, sebanyak 216 siswa. Sampel dipilih 3 kelas dengan teknik random sampling dari 6 kelas. Data pemahaman konsep matematika dikumpulkan dengan tes pemahaman konsep matematika. Analisis data dilakukan dengan uji nonparametric Kruska-Wallis dan uji U Mann Whitney. Hasil pengujian hipotesis menunjukkan bahwa: (1) terdapat perbedaan pemahaman konsep matematika antara siswa yang mengikuti pembelajaran dengan model penemuan terbimbing berbantuan GeoGebra, pembelajaran dengan model penemuan terbimbing, dan pembelajaran dengan model konvensional; (2) pemahaman konsep matematika siswa yang mengikuti pembelajaran dengan model penemuan terbimbing berbantuan GeoGebra lebih baik daripada pembelajaran dengan model penemuan terbimbing; (3) pemahaman konsep matematika siswa yang mengikuti pembelajaran dengan model penemuan terbimbing berbantuan Geogebra lebih baik daripada pembelajaran dengan model konvensional. (4) pemahaman konsep matematika siswa yang mengikuti pembelajaran dengan model penemuan terbimbing lebih baik daripada pembelajaran dengan model konvensional. Jadi dapat disimpulkan bahwa terdapat pengaruh model penemuan terbimbing berbantuan GeoGebra terhadap pemahaman konsep matematika siswa.
\end{abstract}

Kata Kunci : model pembelajaran penemuan terbimbing, GeoGebra, pemahaman konsep matematika

\begin{abstract}
This research was aimed at finding out whether there was significant difference in mathematical conceptual understanding among the students who were taught by using guided discovery learning model with GeoGebra, guided discovery learning model, and conventional model. Based on it, we investigated which group has better mathematical conceptual understanding. This quasi experimental research used post-test only control group design. The population of this reseach was seventh grade students of SMP Negeri 2 Seririt in academic year $2016 / 2017$, by number of 216 students which distributed into six classes. Then, by using random sampling technique obtained 3 classes as sample. The data of mathematical conceptual understanding were collected by using test of mathematical conceptual understanding, then it was analyse by using nonparametric test (Kruska-Wallis and $U$ Mann Whitney test). The results showed that: (1) there was significant difference in mathematical conceptual understanding among the students who were taught by using guided discovery learning model with GeoGebra, guided discovery learning model, and conventional model; (2)
\end{abstract}


mathematical conceptual understanding of students who were taught by using guided discovery learning model with GeoGebra is better than guided discovery learning model; (3) mathematical conceptual understanding of students who were taught by using guided discovery learning model with GeoGebra is better than conventional model; (4) mathematical conceptual understanding of students who were taught by using guided discovery learning model is better than conventional model. It can be conclude that guided discovery learning model with GeoGebra influences positively towards mathematical conceptual understanding.

keyword : guided discovery learning model, GeoGebra, mathematical conceptual understanding

\section{PENDAHULUAN}

Pendidikan merupakan faktor utama dalam pembentukkan baik atau buruknya pribadi manusia. Oleh sebab itu dengan sistem pendidikan yang baik diharapkan muncul generasi penerus bangsa yang berkualitas dan mampu menyesuaikan diri untuk hidup bermasyarakat, berbangsa dan bernegara.

Pada Undang - Undang RI No. 20 tahun 2003 tentang Sistem Pendidikan Nasional Pasal 1 ayat (1) dijelaskan Pendidikan adalah usaha sadar dan terencana untuk mewujudkan suasana belajar dan proses pembelajaran agar siswa aktif mengembangkan potensi dirinya, untuk memiliki kekuatan spiritual keagamaan, pengendalian diri, kepribadian, kecerdasan, akhlak mulia, serta keterampilan yang diperlukan masyarakat bangsa dan Negara. Melihat begitu pentingnya pendidikan, seharusnya kesadaran terhadap pendidikan semakin meningkat di masyarakat tetapi kenyataannya prestasi, moral dan etika bangsa ini terus merosot. Sehingga pemerintah harus terus memperhatikan pendidikan disetiap jenjangnya.

Pada setiap jenjang pendidikan mulai dari sekolah dasar hingga perguruan tinggi tidak terlepas dari mata pelajaran matematika. Dalam kehidupan sehari-hari matematika memegang peranan penting karena matematika tidak hanya diterapkan pada saat belajar matematika itu sendiri tetapi matematika juga diterapkan pada bidang ilmu pengetahuan yang lain. Selain itu, memahami matematika tidak cukup hanya dengan menghafal rumus-rumus saja, tetapi membutuhkan pengertian dan pemahaman konsep secara mendalam. Penguasaan konsep bukan hanya untuk keterampilan dalam mengerjakan soal sebagai aplikasi dari konsep matematika yang diajarkan melainkan lebih ditekankan pada terbentuknya suatu konsep.

Hal tersebut sangat terlihat jelas bahwa pemahaman konsep sangat dibutuhkan dalam pembelajaran matematika. Menurut NCTM (2000) untuk mencapai pemahaman yang bermakna maka pembelajaran matematika harus diarahkan pada pengembangan kemampuan koneksi matematik antar berbagai ide, memahami bagaimana ide-ide matematik saling terkait satu sama lain sehingga terbangun pemahaman menyeluruh, dan menggunakan matematik dalam konteks di luar matematika.

Pemahaman konsep matematika merupakan landasan penting untuk berpikir dalam menyelesaikan permasalahan matematika maupun permasalahan seharihari. Pentingnya pemahaman konsep matematika terlihat dalam tujuan pertama pembelajaran matematika menurut pendapat dari Brunner (dalam Suherman, 2003:43), "Belajar matematika akan lebih berhasil jika proses pengajaran diarahkan kepada konsep-konsep dan struktur-struktur yang terbuat dalam pokok bahasan yang diajarkan, di samping hubungan yang terkait antara konsep dan struktur-struktur". Pentingnya penguasaan konsep dalam pelajaran matematika juga diperkuat dengan pendapat Depdiknas yaitu memahami 
konsep matematika, menjelaskan keterkaitan antar konsep dan mengaplikasikan konsep atau algoritma secara luwes, akurat, efisien dan tepat dalam pemecahan masalah. Jadi dapat dikatakan bahwa pemahaman konsep matematika merupakan bagian yang paling penting dalam pembelajaran matematika karena konsep tidak bisa diterima begitu saja tanpa pemahaman dan penalaran. Hal ini berarti bahwa mata pelajaran matematika menekankan pada konsep. Artinya dalam mempelajari matematika siswa harus memahami konsep matematika terlebih dahulu agar dapat menyelesaikan soal-soal dan mampu mengaplikasikan pembelajaran tersebut dalam dunia nyata.

Meskipun demikian, nampaknya pemerintah bersama pendidik harus berupaya lebih kreatif dan inovatif dalam meningkatkan kemampuan pemahaman konsep matematika siswa. Salah satu bukti rendahnya pemahaman konsep matematika siswa Indonesia diantaranya seperti yang termuat dalam Mendikbud yaitu rata-rata nilai Ujian Nasional (UN) 2015 tingkat SMA/SMK/MA mengalami kenaikan sebanyak 0,3 poin dari tahun sebelumnya 61 menjadi 61,3 tetapi untuk program studi IPA, nilai rata-rata matematika mengalami penurunan dari sebelumnya 60,4 menjadi 59,17 . Nilai matematika tingkat SMP pada tahun 2016 juga mengalami penurunan sebanyak 6,04 poin yaitu dari tahun 2015 sebesar 56,28 menjadi 50,24 pada tahun 2016.

Melihat dari hasil UN matematika tahun 2015 dan 2016 tampak bahwa prestasi belajar matematika siswa sangat rendah. Hal ini dimungkinkan karena siswa mengalami kesulitan dalam memahami konsep matematika. Rendahnya pemahaman konsep siswa dapat diatasi dengan memberikan inovasi baru dalam membelajarkan siswa, dimana pembelajaran tersebut dapat membuat siswa menjadi lebih aktif dalam kegiatan pembelajaran dan mencari berbagai sumber informasi yang relevan untuk menunjang kegiatan pembelajarannya, sehingga kegiatan pembelajaran akan menjadi lebih bermakna dan siswa tidak hanya sekedar menghafal materi yang diajarkan.

Menyikapi hal tersebut, pembelajaran matematika di sekolah perlu dirancang untuk membiasakan siswa mengkontruksi sendiri pengetahuannya dan yang dapat mendukung serta mengarahkan siswa untuk meningkatkan pemahaman konsep matematikanya. Salah satu model pembelajaran yang dapat dijadikan alternatif dalam menumbuhkembangkan aktivitas siswa adalah model penemuan terbimbing. Model penemuan terbimbing ini sangat tepat digunakan mengingat fungsi model penemuan berupaya membantu siswa mengembangkan kemampuan berfikir ilmiah dengan bantuan atau bimbingan dari guru agar siswa lebih terarah dalam menyelesaikan permasalahan yang berkaitan dengan kehidupan nyata (Suprihatiningrum, 2013).

Hanafiah, dkk (2009) menyatakan bahwa model penemuan terbimbing merupakan rangkaian pembelajaran dimana siswa diberikan kesempatan untuk menemukan dan mengkontruksi sendiri ide matematika dengan melibatkan seluruh kemampuan siswa untuk mencari dan menyelidiki secara sistematis, kritis dan logis sehingga mereka dapat menemukan sendiri pengetahuan, sikap dan keterampilan sebagai wujud adanya perubahan tingkah laku. Pembelajaran dengan menggunakan model penemuan terbimbing bertujuan untuk memperbaiki pola pengajaran yang selama ini hanya mengarah kepada menghafal fakta-fakta saja, tetapi tidak memberikan kepada siswa pengertian konsep-konsep dan atau prinsip-prinsip yang terdapat dalam suatu materi pelajaran.

Pembelajaran penemuan terbimbing membuat siswa terbiasa mandiri menyelesaikan permasalahan dimana daya ingat siswa lebih lama membekas dalam memahami topik yang diberikan melalui panduan atau bimbingan yang dilakukan guru. Membimbing siswa dalam mengembangkan pemahaman jauh lebih mengasyikkan dibandingkan sekedar 
menjelaskan topik yang diberikan sehingga timbulnya interaksi antara siswa dan guru. Keterlibatan siswa dalam proses pembelajaran menyebabkan siswa tertarik untuk belajar. Pembelajaran penemuan terbimbing menghendaki siswa yang belajar secara aktif dan menumbuhkan semangat siswa dalam menemukan penyelesaian dari masalah yang diberikan dan membuat siswa lebih lama mengingat apa yang sudah dipelajari karena siswa tidak hanya sekedar belajar tetapi siswa lebih tepatnya membangun suatu konsep.

Dalam proses pembelajaran matematika sering terlihat siswa kesulitan dalam memahami materi dan dalam pemberian tugas hanya beberapa saja yang mau mengerjakan. Hal ini disebabkan pembelajaran matematika yang monoton sehingga siswa merasa bosan dalam belajar. Berkaitan dengan hal tersebut perlu dilakukan inovasi-inovasi dalam pembelajaran matematika. Salah satu inovasi dalam pembelajaran matematika adalah pembelajaran dengan menggunakan media yang berfungsi sebagai sarana untuk mencapai tujuan pembelajaran dan juga memiliki peranan penting dalam menunjang kualitas proses belajar mengajar. Media yang sesuai dengan perkembangan zaman saat ini adalah media komputer. Salah satu aplikasi atau program komputer yang dapat dimanfaatkan sebagai media pembelajaran matematika yaitu geogebra.

Geogebra adalah perangkat lunak yang dinamis (dynamic), bebas (free) dan multi-flatform menggabungkan geometri, aljabar, tabel, grafik, statistik dan kalkulus (siswanto, (2014). Software ini pertama dikembangkan oleh Hohenwater. Salah satu manfaat dari media geogebra menurut Hohender dan Fuchs (dalam Nur, 2016) adalah sebagai alat bantu proses penemuan, yaitu bahwa geogebra dapat digunakan sebagai alat bantu bagi siswa untuk menemukan suatu konsep matematika tertentu.

Berkaitan dengan model pembelajaran penemuan terbimbing dan media Geogebra, Yoppy Wahyu Purnomo
(2011) melakukan penelitian dengan judul "Keefektifan Model Penemuan Terbimbing dan Cooperative Learning Pada Pembelajaran Matematika" dimana hasil penelitian menunjukkan model guided discovery dan cooperative learning memberikan hasil yang tidak berbeda tetapi dampak terhadap hasil belajar siswa, keduanya lebih baik daripada model pembelajaran konvensional. Berdasarkan uraian di atas, tampak bahwa model pembelajaran penemuan terbimbing memberikan pengaruh yang positif pada hasil belajar siswa dalam pembelajaran matematika. Pemahaman konsep tentu memiliki keterkaitan yang erat dengan hasil belajar. Pemahaman konsep merupakan salah satu kemampuan dalam menangkap makna dan arti dari bahan yang dipelajari dalam proses pembelajaran yang dapat mendukung hasil belajar siswa.

Dalam penelitian yang dilakukan Yoppy belum terdapat suatu media pendukung dalam pembelajaran, padahal media sangat dapat membantu proses pembelajaran matematika untuk lebih mudah dipahami. Salah satu penelitian menggunakan media dalam pembelajaran matematika yakni penelitian yang dilakukan oleh Sudarmawa (2014) dengan judul "Pengaruh Strategi Pembelajaran Van Hiele berbantuan Geogebra terhadap Pemahaman Konsep Geometri Siswa Kelas VII SMP Lab Undiksha Singaraja" menemukan bahwa hasil penelitian menunjukkan strategi pembelajaran Van Hiele berbantuan geogebra lebih baik daripada pembelajaran konvensional. Berdasarkan hasil penelitiannya terlihat peran media geogebra dalam pembelajaran matematika sangat berpengaruh dalam pemahaman konsep matematika siswa.

Berdasarkan uraian yang telah dipaparankan di atas, model pembelajaran penemuan terbimbing berbantuan Geogebra diyakini berpengaruh terhadap pemahaman konsep matematika siswa. Namun secara empiris belum dapat dibuktikan. Oleh karena itu penulis tertarik untuk melakukan penelitian yang berjudul 
Jurnal Pendidikan Matematika Undiksha, Volume IX No 1, April 2018 e-ISNN:2599-2600; p-ISNN: 2613-9677

\begin{abstract}
"Pengaruh model Pembelajaran Penemuan Terbimbing berbantuan GeoGebra terhadap Pemahaman Konsep Matematika Siswa Kelas VII SMP Negeri 2 Seririt".
\end{abstract}

\section{METODE}

Jenis penelitian yang digunakan merupakan eksperimen semu (quasi eksperimen). Populasi dalam penelitian ini adalah siswa Kelas VII SMP Negeri 2 Seririt tahun ajaran 2016/2017 yang sudah dikelompokkan dalam kelas-kelas yang berjumlah 216 orang siswa yang tersebar ke dalam 6 kelas. Teknik pengambilan sampel pada penelitian ini dilakukan dengan random sampling, yaitu pengambilan sampel dilakukan secara acak tanpa memperhatikan strata yang ada dalam populasi itu. Dari hasil pengundian, diperoleh Kelas VIIA sebagai kelompok eksperimen, kelas VIIC sebagai kelompok komparasi dan Kelas VIIIF sebagai kelompok kontrol.
Data yang diperoleh pada penelitian ini merupakan data pemahaman konsep matematika siswa yang diperoleh melalui tes yang berbentuk uraian. Setelah kelas sampel diberikan perlakuan, dilakukan pengujian terhadap hipotesis yang diajukan. Data yang diperoleh terlebih dahulu diuji normalitas dan homogenitasnya. Karena data pemahaman konsep tidak berdistribusi normal, maka data pemahaman konsep tidak memenuhi asumsi ANAVA satu jalur, dengan demikian uji yang digunakan yaitu uji pada nonparametric yaitu uji Kruskal-Wallis dan uji U Man Withney.

\section{HASIL PENELITIAN}

Data kemampuan pemahaman konsep matematika siswa diperoleh dari hasil posttest yang telah diberikan kepada kedua kelompok sampel dapat dilihat pada Tabel 1 berikut.

Tabel 1. Rangkuman Analisis Data Kemampuan Pemahaman Konsep Matematika Siswa

\begin{tabular}{cccc}
\hline \multirow{2}{*}{ Variabel } & Eksperimen & \multicolumn{2}{c}{ Kelas Sampel } \\
& Komparasi & Kontrol \\
\hline $\mathrm{n}_{\mathrm{i}}$ & 36 & 36 & 36 \\
\hline $\bar{Y}$ & 73,26 & 65,45 & 57,81 \\
\hline $\mathrm{SD}$ & 11,43 & 10,51 & 11,31 \\
\hline
\end{tabular}

Normalitas sebaran data ketiga sampel penelitian ini diuji dengan uji kolmogorov Smirnov, sedangkan homogenitas varians dari kedua sampel diuji dengan uji Levene. Setelah dianalisis diperoleh data pada kelompok ekperimen dan komparasi yaitu 0,198 dan 0,166, keduanya kurang dari $D_{\text {tabel }}$ yaitu 0,221 sedangkan pada kelompok kontrol tidak berdistribusi normal, ini dapat dilihat dari nilai

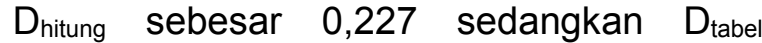
sebesar 0,221 , terlihat $D_{\text {hitung }}>D_{\text {tabel. }}$. Maka tolak $\mathrm{H}_{0}$. Sehingga dapat disimpulkan data pemahaman konsep tidak berdistribusi normal. Untuk menguji hipotesis penelitian digunakan uji nonparametrik yaitu uji Kruskal-Wallis dan uji $U$ man Withney dikarenakan asumsi pada uji ANAVA satu jalur tidak terpenuhi.

Pada uji Kruskal-Wallis Nilai $H$ yang diperoleh dibandingkan dengan tabel $x^{2}$ dengan dk pembilang ( $\mathrm{k}-1)$ dan Jika nilai signifikansi $z<5 \%$, maka $\mathrm{H}_{0}$ ditolak. Rangkuman dengan pengujian hipotesis dengan uji Kruskal-Wallis dapat dilihat pada tabel 2.

Tabel 2. Rangkuman uji Kruskal-Wallis 
Jurnal Pendidikan Matematika Undiksha, Volume IX No 1, April 2018 e-ISNN:2599-2600; p-ISNN: 2613-9677

\begin{tabular}{ccccccccc}
$\begin{array}{c}\text { Mean } \\
\boldsymbol{R}_{\boldsymbol{1}}\end{array}$ & $\begin{array}{c}\text { Mean } \\
\boldsymbol{R}_{\boldsymbol{2}}\end{array}$ & $\begin{array}{c}\text { Mean } \\
\boldsymbol{R}_{\mathbf{3}}\end{array}$ & $\boldsymbol{d} \boldsymbol{k}$ & $\boldsymbol{N}$ & $\sum T$ & $\mathbf{H}$ & $\begin{array}{c}\mathbf{H} \\
\text { tabel }\end{array}$ & Keputusan \\
\hline 73,61 & 53,78 & 36,11 & 2 & 108 & 33960 & 26,547 & 5,90 & Tolak Ho \\
\hline
\end{tabular}

Berdasarkan hasil analisis data pada Tabel 2 diperoleh bahwa $H_{\text {hitung }}>\mathrm{X}^{2}$ tabel. Dengan demikian $H_{0}$ ditolak. Kesimpulannya adalah terdapat perbedaan pemahaman konsep matematika antara siswa yang mengikuti pembelajaran penemuan terbimbing berbantuan geogebra, siswa yang mengikuti pembelajaran penemuan terbimbing dan siswa yang mengikuti pembelajaran konvensional. Untuk mencari mana yang lebih tinggi maka perlu dilakukan uji lanjut untuk mengetahui kelompok siswa mana yang lebih tinggi.

Oleh karena itu, Uji Lanjut menggunakan uji $U$ Mann Whitney pada masing-masing model pembelajaran yang ingin dibandingkan. Adapun hasil pengujian hipotesis tersebut secara berurutan sebagai berikut.

Pengujian hipotesis kedua dapat dilihat pada tabel 3 yaitu rangkuman hasil analisis uji $U$ Mann Withney pada kelas eksperimen dan kelas komparasi.

Tabel 3. Rangkuman uji U Man Whitney pada kelas eksperimen dan kelas komparasi

\begin{tabular}{cccccccccc}
\hline $\boldsymbol{R}_{\boldsymbol{1}}$ & $\begin{array}{c}\text { Mean } \\
\boldsymbol{R}_{\boldsymbol{1}}\end{array}$ & $\boldsymbol{R}_{\boldsymbol{2}}$ & $\begin{array}{c}\text { Mean } \\
\boldsymbol{R}_{\boldsymbol{2}}\end{array}$ & $\boldsymbol{U}$ & $\boldsymbol{N}$ & $\sum T$ & $\mathbf{z}$ & $\mathbf{Z}$ tabel & Keputusan \\
\hline 1576,5 & 43,79 & 1051,5 & 29,20 & 910,5 & 72 & 893,5 & 2,99 & 1,6448 & Tolak Ho \\
\hline
\end{tabular}

Berdasarkan hasil analisis data pada Tabel 2 diperoleh bahwa $Z_{\text {hitung }}>Z_{\text {tabel }}$. Dengan demikian $H_{0}$ ditolak. Kesimpulannya adalah pemahaman konsep matematika antara siswa yang mengikuti model pembelajaran penemuan terbimbing berbantuan geogebra lebih tinggi dari siswa yang mengikuti model pembelajaran penemuan terbimbing.

Pengujian hipotesis ketiga dapat dilihat pada tabel 3 yaitu rangkuman hasil analisis uji $U$ Mann Withney pada kelas eksperimen dan kelas kontrol.

Tabel 4. Rangkuman uji U Man Whitney pada kelas eksperimen dan kelas kontrol.

\begin{tabular}{|c|c|c|c|c|c|c|c|c|c|}
\hline$R_{1}$ & $\begin{array}{c}\text { Mean } \\
R_{1} \\
\end{array}$ & $\boldsymbol{R}_{2}$ & $\begin{array}{c}\text { Mean } \\
R_{2} \\
\end{array}$ & $\boldsymbol{U}$ & $N$ & $\sum T$ & $\mathbf{Z}$ & $\mathrm{Z}$ tabel & Keputusan \\
\hline 1739,5 & 48,31 & 888,5 & 24,68 & 1073,5 & 72 & 792 & 4,85 & 1,6448 & Tolak Ho \\
\hline
\end{tabular}

Berdasarkan hasil analisis data pada Tabel 4 diperoleh bahwa $Z_{\text {hitung }}>Z_{\text {tabel }}$. Dengan demikian $H_{0}$ ditolak. Kesimpulannya adalah pemahaman konsep matematika antara siswa yang mengikuti model pembelajaran penemuan terbimbing berbantuan geogebra lebih tinggi dari siswa yang mengikuti model pembelajaran konvensional.

Pengujian hipotesis keempat dapat dilihat pada tabel 5 yaitu rangkuman hasil analisis uji $U$ Mann Withney pada kelas komparasi dan kelas kontrol.

Tabel 5. Rangkuman uji U Man Whitney pada kelas komparasi dan kelas kontrol 
Jurnal Pendidikan Matematika Undiksha, Volume IX No 1, April 2018 e-ISNN:2599-2600; p-ISNN: 2613-9677

\begin{tabular}{cccccccccc}
\hline $\boldsymbol{R}_{\boldsymbol{1}}$ & $\begin{array}{c}\text { Mean } \\
\boldsymbol{R}_{\boldsymbol{1}}\end{array}$ & $\boldsymbol{R}_{\boldsymbol{2}}$ & $\begin{array}{c}\text { Mean } \\
\boldsymbol{R}_{\boldsymbol{2}}\end{array}$ & $\boldsymbol{U}$ & $\boldsymbol{N}$ & $\sum T$ & $\mathbf{z}$ & $\mathbf{Z}$ tabel & Keputusan \\
\hline 1550,5 & 43.06 & 1077,5 & 29,93 & 884,5 & 72 & 1154,5 & 2,71 & 1,6448 & Tolak Ho \\
\hline
\end{tabular}

Berdasarkan hasil analisis data pada Tabel 2 diperoleh bahwa $Z_{\text {hitung }}>Z_{\text {tabel. }}$. Dengan demikian $H_{0}$ ditolak. Kesimpulannya adalah pemahaman konsep matematika antara siswa yang mengikuti model pembelajaran penemuan terbimbing lebih tinggi dari siswa yang mengikuti model pembelajaran konvensional.

\section{PEMBAHASAN}

Berdasarkan uji hipotesis dapat disimpulkan bahwa terdapat perbedaan pemahaman konsep matematika antara siswa yang mengikuti pembelajaran penemuan terbimbing berbantuan geogebra, siswa yang mengikuti pembelajaran penemuan terbimbing dan siswa yang mengikuti pembelajaran konvensional. Pelaksanaan pembelajaran baik yang menggunakan model pembelajaran penemuan terbimbing berbantuan geogebra, model pembelajaran penemuan terbimbing maupun dengan pembelajaaran konvensional, sama-sama menggunakan Lembar Kerja Siswa (LKS) dalam kegiatan pembelajaran. LKS yang digunakan pada pembelajaran konvensional disusun terlalu menuntun siswa dalam menjawab. Siswa hanya melengkapi bagian yang kurang lengkap dan diarahkan mampu menyelesaikan soal secara prosedural saja, sehingga pemahaman siswa terhadap konsep yang diberikan kurang optimal. Namun pada model pembelajaran penemuan terbimbing, LKS tersebut memuat kolom pertanyaan sebagai dugaan sementara terhadap permasalahan, kolom pengamatan, kolom pemecahan masalah dan kolom kesimpulan ini sejalan dengan Jumadi (2013) bahwa penerapan model penemuan terbimbing lebih baik dibandingkan dengan model pembelajaran konvensional. Pada tahapan-tahapan tersebut siswa diarahkan menemukan sendiri konsep yang dipelajari, mulai dari memahami masalah, mengumpulkan data, memecahkan masalah hingga menarik kesimpulan, sehingga pemahaman konsep matematika siswa akan lebih optimal. Namun dalam pembelajaran ini dibutuhkan suatu alat untuk siswa dapat lebih leluasa dalam melakukan eksplorasi sehingga hasil yang didapat akan lebih optimal. Salah satunya bisa menggunakan media pembelajaran.

Media pembelajaran yang digunakan adalah media berbasis geogebra. Software ini secara khusus memang diperuntukkan untuk kepentingan pembelajaran matematika. Tampilannya secara maksimal sudah mengakomodasi representasi konsep matematika secara multimode atau multirepresentasi. Hal ini ditunjukkan dengan adanya jendela untuk rerpresentasi aljabar (analitik), untuk representasi visual (grafis), dan representasi numerik berupa spreadsheet. Keunggulan inilah yang dapat membantu siswa dalam mempelajari objekobjek geometri yang bersifat abstrak. Ini sejalan dengan Tri dan Erny (2012) yang menyatakan siswa lebih termotivasi belajar dengan bantuan Geogebra daripada siswa belajar tanpa menggunakan Geogebra.

Pembelajaran penemuan terbimbing berbantuan geogebra berkontribusi positif dalam pembelajaran khususnya pada materi bangun datar, seperti: 1) visualisasi geometri yang dihasilkan media lebih cepat dan teliti dibandingkan dengan menggunakan pensil, penggaris, atau jangka, dan 2) visual yang dihasilkan bersifat dinamis, perubahan apapun yang terjadi saat siswa menggunakan media ini akan segera diberikan balikan langsung oleh media. Balikan yang diberikan membantu siswa dalam melakukan verifikasi pemahaman yang diperolehnya. Siswa dapat mencocokan maupun membandingkan pemahamannya melalu media yang diberikan. 3) fasilitas animasi dan gerakangerakan manipulasi pada media dapat 
memberikan pengalaman visual yang lebih jelas kepada siswa dalam memahami konsep. Hal ini membuat proses pengumpulan maupun pengolahan data/informasi lebih efektif. Visualisasi geometri yang lebih jelas akan memudahkan siswa dalam membandingkan dan menganalisa objek baik contoh non contoh sebagai informasi yang ingin diperolehnya. Sehingga siswa dapat menyatakan kembali konsep-konsep abstrak ke model-model matematika yang lebih sederhana dengan pengertiannya sendiri. Adanya proses saling interaksi siswa dengan media yang diberikan membuat siswa merasa lebih antusias dan terbantu dalam memahami konsep yang dipelajari. Ini sejalan dengan Sudarmawa (2014) yang menyatakan media geogebra berpengaruh terhadap pemahaman konsep geometri siswa. Sehingga dapat disimpulkan pembelajaran matematika dengan model pembelajaran penemuan terbimbing berbantuan geogebra memberikan pengaruh positif terhadap peningkatan pemahaman konsep matematika siswa.

Berdasarkan pengujian hipotesis
kedua dapat disimpulkan bahwa pemahaman konsep matematika antara siswa yang mengikuti model pembelajaran penemuan terbimbing berbantuan geogebra lebih tinggi dari siswa yang mengikuti model pembelajaran penemuan terbimbing. Hal ini mengindikasi bahwa pembelajaran penemuan terbimbing berbantuan GeoGebra berpengaruh positif terhadap pemahaman konsep siswa. Temuan ini juga didukung hasil penelitian Mehdiyev (2009) yang menyatakan bahwa dengan software geometri dinamis dapat memberikan kesempatan siswa melakukan investigasi untuk memahami konsep geometri. Ini sejalan dengan Tegeh (2010) bahwa teknologi atau alat bantu untuk menyampaikan pengetahuan yang disebut dengan media pembelajaran, akan dapat merangsang perhatian, minat, pikiran, dan perasaan siswa apabila sejalan dengan esensi tujuan pengajaran yang telah dirumuskan. Untuk itu tindakan guru memfasilitasi siswa merupakan hal yang sangat penting dan sangat berpengaruh terhadap proses pembelajaran salah satunya menggunakan media pembelajaran. Temuan ini sejalan dengan Sudarmawa (2014) yang mengatakan bahwa siswa yang dibelajarkan dengan Geogebra lebih baik dari siswa yang dibelajarkan tanpa Geogebra terhadap pemahaman konsep geometri siswa. Geogebra dalam penelitian ini membantu dalam visualisasi bangun datar tepatnya segitiga dan segiempat, sebagai media untuk siswa melakukan eksplorasi dan membantu siswa melakukan eksperimeneksperimen untuk menyelesaikan permasalahan selama pembelajaran. Visualisasi bangun datar dengan GeoGebra membantu siswa dalam membayangkan bangun yang dimaksudkan sehingga dengan mudah siswa mengetahui gambaran mengenai materi yang akan dibahas atau mengingat kembali terkait materi sebelumnya. Dengan bantuan geogebra, dapat dilakukan visualisasi bangun datar dalam jumlah banyak dan dapat menampilkan unsur-unsur yang diperlukan, seperti: panjang sisi, besar sudut, dan lainlain secara langsung.

Melalui media geogebra Siswa dapat melakukan perintah untuk membuat bangun datar dengan mudah. Pada penelitian ini siswa lebih banyak melakukan eksperimen dengan manipulasi bangun-bangun datar yang sudah disiapkan oleh guru. Siswa menggeser slider untuk mengubah ukuran suatu objek atau menggeser objek tersebut secara langsung, respon perubahan dapat terlihat dengan cepat sehingga mempermudah siswa dalam melakukan pengamatan. Dari beberapa percobaan yang dilakukan, siswa akan melihat hubungan dan mencoba membuat generalisasi dengan kata-katanya sendiri. Hal ini memperlihatkan bahwa siswa secara aktif melakukan eksplorasi untuk mengkonstruksi sendiri pemahamannya. 
Berdasarkan pengujian hipotesis
ketiga dapat disimpulkan bahwa pemahaman konsep matematika antara siswa yang mengikuti model pembelajaran penemuan terbimbing berbantuan geogebra lebih tinggi dari siswa yang mengikuti model pembelajaran konvensional. Model pembelajaran penemuan terbimbing dengan berbantuan media geogebra dalam hal ini dapat menyajikan atau memvisualisasikan konsep matematika yang bersifat abstrak menjadi mudah untuk dipahami. Visualisasi geometri yang dihasilkan media geogebra lebih cepat dan teliti dibandingkan dengan menggunakan pensil, penggaris, atau jangka. Temuan ini sesuai dengan hasil penelitian Abdul Saha, Mohd Ayub, dan Tarmizi (2010) yang menyatakan bahwa GeoGebra lebih efektif sebagai media dalam membantu proses pembelajaran geometri dibandingkan dengan media pembelajaran tradisional. Ini sejalan dengan Tri dan Erny (2012) yang menyatakan siswa lebih termotivasi belajar dengan bantuan Geogebra daripada siswa belajar tanpa menggunakan Geogebra. Melalui media geogebra Visual yang dihasilkan bersifat dinamis, perubahan apapun yang terjadi saat siswa menggunakan media ini akan segera diberikan balikan langsung oleh media. Hal ini membuat proses pengumpulan maupun pengolahan data/informasi lebih efektif. Visualisasi geometri yang lebih jelas akan memudahkan siswa dalam membandingkan dan menganalisa objek baik contoh non contoh sebagai informasi yang ingin diperolehnya. Sehingga siswa dapat menyatakan kembali konsep-konsep abstrak ke model-model matematika yang lebih sederhana dengan pengertiannya sendiri.

Berdasarkan pengujian hipotesis
keempat dapat disimpulkan bahwa
pemahaman konsep matematika antara
siswa yang mengikuti model pembelajaran
penemuan terbimbing lebih tinggi dari siswa
yang mengikuti model pembelajaran
konvensional. Secara umum pelaksanaan
pembelajaran matematika dengan model

penemuan terbimbing telah berjalan sesuai dengan yang diharapkan. Siswa yang belajar dengan model penemuan terbimbing melakukan pengamatan, menyelidiki dan membuat kesimpulan untuk menemukan konsep. Dengan melakukan proses berpikir untuk menemukan konsep, pemahaman konsep yang diperoleh siswa lebih bermakna. Hambatan dalam pembelajaran penemuan terbimbing adalah kemampuan siswa yang bervariasi, sehingga tingkat kesulitan yang dihadapi siswa sangat beragam dalam menemukan konsep. Kendala lain adalah pembelajaran matematika dengan model penemuan terbimbing merupakan pembelajaran yang baru bagi siswa, sehingga pada pertemuan pertama siswa merasa bingung dan mengalami kesulitan karena biasanya guru menjelaskan materi yang akan dipelajari dan memberi contoh soal dan penyelesaiannya. Dalam proses penemuan konsep, siswa mendapat bantuan dari guru, bantuan yang diberikan manakala siswa tersebut mengalami kesulitan di atas kemampuannya dalam memecahkan masalah, antara lain berupa pengajuan pertanyaan. Pertanyaan yang diberikan oleh guru berbentuk pertanyaan yang lebih sederhana dan lebih mengarahkan siswa untuk dapat untuk mengonstruksi konsep. Bentuk pertanyaan tersebut merupakan lanjutan dari pertanyaan yang dituangkan dalam LKS, bantuan yang diberikan bukan untuk individu melainkan untuk kelompok.

Berhasil atau tidaknya siswa dalam menemukan konsep sangat tergantung pada pertanyaan-pertanyaan yang disajikan dalam Lembar Kerja Siswa (LKS) dan pertanyaan-pertanyaan lisan yang diberikan guru untuk memancing siswa berpikir. Pertanyaan yang diajukan harus terjangkau oleh pikiran siswa sehingga siswa dengan mudah memahami dan mengonstruksi konsep-konsep, Hal itu dilakukan, agar tidak membuat siswa gagal dalam menemukan konsep ataupun agar siswa tidak kehilangan semangat belajar. 
Pembelajaran matematika dengan menggunakan model penemuan terbimbing, mampu menciptakan suasana belajar aktif antar siswa, suasana belajar ini dapat menyebabkan terjadi interaksi antara siswa baik dalam kelompok. Sebagian besar siswa memiliki sikap positif terhadap pembelajaran matematika dengan model penemuan terbimbing. Dalam melakukan aktivitas penemuan, siswa berinteraksi dengan siswa lainnya. Interaksi berupa sharing atau siswa yang berkemampuan lemah bertanya kepada siswa yang pandai kemudian siswa yang pandai menjelaskannya. Dengan demikian siswa akan berusaha lebih keras untuk memahami dan mengkontruksi konsep-konsep.

\section{SIMPULAN DAN SARAN}

Berdasarkan hasil penelitian dapat disimpulkan bahwa pemahaman konsep matematika siswa yang menggunakan model pembelajaran penemuan terbimbing berbantuan geogebra lebih baik daripada siswa yang menggunakan model pembelajaran penemuan terbimbing dan siswa yang mengikuti pembelajaran konvensional. Hal ini dilihat berdasarkan adanya perbedaan pemahaman konsep matematika antara siswa yang mengikuti pembelajaran dengan model pembelajaran penemuan terbimbing berbantuan GeoGebra, siswa yang mengikuti pembelajaran dengan model pembelajaran penemuan terbimbing, dan siswa yang mengikuti pembelajaran dengan model konvensional; Pemahaman konsep matematika siswa yang mengikuti pembelajaran dengan model pembelajaran penemuan terbimbing berbantuan GeoGebra lebih baik daripada siswa yang mengikuti pembelajaran dengan model pembelajaran penemuan terbimbing; Pemahaman konsep matematika siswa yang mengikuti pembelajaran dengan model pembelajaran penemuan terbimbing berbantuan GeoGebra lebih baik daripada siswa yang mengikuti pembelajaran dengan model pembelajaran konvensional; Pemahaman konsep matematika siswa yang mengikuti pembelajaran dengan model pembelajaran penemuan terbimbing lebih baik daripada siswa yang mengikuti pembelajaran dengan model pembelajaran konvensional

Berdasarkan temuan tersebut disarankan kepada guru mata pelajaran matematika agar menerapkan penemuan terbimbing dalam pembelajaran geometri khususnya bangun datar di kelas, dan mengembangkan media pembelajaran dengan GeoGebra agar pelaksanaan pembelajaran dapat berjalan efektif. Bagi peneliti selanjutnya yang berminat melakukan penelitian yang relevan agar mencoba melihat pengaruh model pembelajaran penemuan terbimbing terhadap variabel lain misalnya motivasi dan prestasi.

\section{DAFTAR PUSTAKA}

Arikunto, S. 2002. Dasar-dasar Evaluasi Pendidikan. Jakarta: Bumi Aksara.

Candiasa, I. M. 2010a. Pengujian Instrumen Penelitian Disertai Aplikasi ITEMAN dan BIGSTEPS. Singaraja: Universitas Pendidikan Ganesha.

Candiasa, I. M. 2010b. Statistik Univariat dan Bivariat Disertai Aplikasi SPSS. Singaraja: Universitas Pendidikan Ganesha.

Daryanto. 2008. Evaluasi Pendidikan. Jakarta: Rineka Cipta.

Djamarah, S. B \& Zain, A. 2006. Strategi Belajar Mengajar. Jakarta: PT Asdi Mahasatya.

Enny , M. CH. \& Tri, W. Y. 2012. Pengaruh Media Pembelajaran GeoGebra Terhadap Motivasi dan Hasil Belajar Siswa pada Materi Grafik 
Jurnal Pendidikan Matematika Undiksha, Volume IX No 1, April 2018 e-ISNN:2599-2600; p-ISNN: 2613-9677

Fungsi Kuadrat di Kelas X SMA Negeri 2 Yogjakarta Tahun Pelajaran 2012/2013. Tersedia pada Error! Hyperlink reference not valid._(diakses pada tanggal 28 agustus 2016)

Hanafiah, dkk. 2009. Konsep strategi pembelajaran. Bandung: PT. refika Aditama.

Hosnan, M. 2014. Pendekatan Saintifik dan Kontekstual dalam Pembelajaran Abad 21. Bogor: Ghalia Indonesia.

Indahsari, N, L. 2016. Perancangan Perangkat Pembelajaran Matematika Berbantuan Ge oGebra Pada Sub Pokok Bahasan Nilai-Nilai Stasioner di Kelas XI IPA dengan Pendekatan Klasikal. Vol. 2, N0.2, April 2016. Tersedia http://portal.widyamandala.ac.id . (diakses pada 28 Agustus 2016)

Jumadi. 2013. Penerapan Pembelajaran Penemuan Terbimbing untuk Meningkatkan Hasil Belajar Matematika Bagi Siswa Kelas VII SMP Negeri 9 Malang. Tersedia pada http://library.um.ac.id/ptk/index. php?mod =detail\&id =59895 (diakses 28 agustus 2016)

Mehyidev, R. 2009. Exploring students' learning experiences when using a Dynamic Geometry Software (DGS) tool in a geometry class at a secondary school in Azerbaijan. Tesis AMSTEL Institute Universiteit van Amsterdam.

Markaban. 2006. Model Pembelajaran Matematika dengan Pendekatan Penemuan Terb imbing.
Yogjakarta: Pusat Pengembangan dan Penataran Guru Matematika.

Mendikbud. "Rata-rata nilai Ujian Nasional naik 0,3 poin". Tersedia pada http://litbang.kemdikbud.go.id/in dex.php/home2-9/1195-mendik bud-rata-rata-nilai-ujiannasional-naik-0-3-poin ( diakses pada 15 Oktober 2016)

NCTM. 2000. Mathematics Assessment: A Pratical Handbook for Grades 68. United State of America : NCTM.

Pruwanto, C.E. dkk. 2012. Penerapan model pembelajaran guided discovery pada materi pemantulan cahaya untuk meningkatkan berfikir kritis.

Rustaman. 2013. Pengembangan Model Pembelajaran (MIPA). Makalah pada Seminar Nasional Pengembangan Pembelajaran MIPA dan Implementasinya dalam pelaksanaan KBK. Semarang: FMIPA IKIP PGRI Semarang.

Satyawati, N. N. S. B. 2012. Pengaruh model pembelajaran penemuan terbimbing Berbasis LKS Terhadap Hasil Belajar Matematika Siswa Ditinjau Dari Kecerdasan Logis Matematis Pada Siswa Kelas X SMA N 1 Bangli. Tesis tidak diterbitkan. Singaraja:

Program Pascasarjana Universitas Pendidikan Ganesha.

Sisdiknas, 2003. "Undang-Undang Republik Indonesia Nomor 20 Tahun 2003 Tentang Sistem Pendidikan Nasional. Dapat diakses pada Error! Hyperlink 
Jurnal Pendidikan Matematika Undiksha, Volume IX No 1, April 2018 e-ISNN:2599-2600; p-ISNN: 2613-9677

reference not valid.. Diakses pada tanggal 25 Agustus 2016.

Siswanto, R. 2014. Peningkatan Kemampuan Penalaran Dan Koneksi Matematis Melalui Penerapan Model Pembelajaran Kooperatif Tipe Stad Berbantuan Software Geogebra (Studi Eksperimen Di SMAN 1 Cikulur Kabupaten Lebak Propinsi Banten). Vol. 1 No. 1, 2014, artikel 7. Tersedia pada http://pasca.ut. ac.id/journa l/index.php /JPK larticle/download/11/11 (diakses pada 28 Agustus 2016)

Suciptawati. N.L.P. 2009. Metode Statistika Nonparametrik. Denpasar: Udayana University Press.

Sudarmawa, M. 2014. Pengaruh Strategi Pembelajaran Van Hiele berbantuan Geogebra terhadap Pemahaman Konsep Geometri Siswa Kelas VII SMP Lab Undiksha Singaraja.Vol 2 No 1. Tersedia pada Error! Hyperlink reference not valid. (diakses pada tanggal 28 Agustus)

Sudjana. 1996. Metode Statistika. Bandung: Tarsito.

Sugiyono. 2012. Metode Penelitian Pendidikan. Bandung: Alfabeta.

Suherman, E. 1993. Evaluasi Proses dan Hasil Belajar Matematika. Modul. Universitas Terbuka, Depdikbud. Jakarta.

Suherman, E. 2003. Strategi Pembelajaran Matematika Kontemporer. Bandung: Jurusan Pendidikan Matematika FMIPA UPI
Sugiyono, 2009. Metode penelitian kuantitatif kualitatif dan R\&D. Bandung: Alfabeta.

Suprihatiningrum, J. 2013. Strategi pembelajaran (teori dan aplikasi). Yogjakarta: Ar-Ruzz media

Suryosubroto, B. 1996. Proses Belajar Mengajar di Sekolah. Jakarta: Rineka Cipta.

Tegeh, I M. \& Kirna, I M. 2010. Metode Penelitian Pengembangan Pendidikan. Singaraja: Univ ersitas Pendidikan Ganesha.

Wahyu, P.Y (2010). Keefektifan Model Penemuan Terbimbing dan Cooperative Learning pada Pembelajaran Matematika di SMP Negeri 3 Satu Atap Jatipurno. Vol 11 No 1. Tersedia pada Error! Hyperlink reference not valid. (diakses pada 28 agustus 2016) 